\title{
Trabajos Seleccionados
}

\section{PRESENTACIONES ORALES}

\section{La activación de NRF2 por el compuesto A (CPDA) protege a las células-ß de la injuria inflamatoria mediada por citoquinas}

Luz Andreone $^{1}$, Carolina Sétula ${ }^{1}$, Juan Manuel Assad ${ }^{1}$, Marcelo Javier Perone ${ }^{1}$

1 INSTITUTO DE INVESTIGACIONES EN MEDICINA TRASLACIONAL (IIMT), CONSEJO NACIONAL DE INVESTIGACIONES CIENTÍFICAS Y TÉCNICAS (CONICET), UNIVERSIDAD AUSTRAL, CIUDAD AUTÓNOMA DE BUENOS AIRES, ARGENTINA

Contacto: luzandreone@gmail.com

Introducción: el desarrollo del proceso autoinmune durante la diabetes tipo 1 (DM1) contribuye a la insulitis; en este contexto, el estrés de las células- $ß$ y su posterior deficiencia en la secreción de insulina preceden a los signos clínicos de la enfermedad. La hiperglucemia desencadena la producción de especies reactivas de oxígeno (ROS) mitocondriales que superan la capacidad antioxidante de las células- $ß$ conduciendo al estrés oxidativo. El microambiente inflamatorio del islote contribuye a la activación del estrés oxidativo y del retículo endoplásmico (RE) resultando en la disfunción y muerte de las células- $\beta$. El factor de transcripción Nrf2 regula la expresión de genes citoprotectores en respuesta al estrés oxidativo, su inducción es necesaria para la fisiología normal de la célula-ß. Hemos reportado que el $C p d A$ regula células inmunes clave en la respuesta inmune e inflamatoria y en la insulitis, linfocitos $T$ y células dendríticas. También observamos que el CpdA disminuye el estrés de RE inducido por citoquinas inflamatorias (IL-1ß+IFN-g; CYT) en células- $\beta$ y que la administración in vivo del CpdA retarda la aparición de hiperglucemia en un modelo murino de diabetes autoinmune. El desarrollo de nuevos agentes con acción antiinflamatoria e inmunomoduladora y potencial protector dirigido a la señalización disfuncional de las células- $ß$ posee interés clínico en la diabetes.

Objetivos: explorar el efecto del CpdA sobre la vía de señalización de Nrf2 y el estrés oxidativo inducido por CYT en las células-ß.

Materiales y métodos: como modelo experimental utilizamos la línea celular de insulinoma de rata (INS-1E). Fórmula química del CpdA: cloruro de 2-(4-acetoxifenil)-2cloro-N-metil-etilamonio. Se utilizó un plásmido reportero (ARE-LUC) para la evaluación de la actividad transcripcional de Nrf2 (luminometría), RT-qPCR (Sybr Green) para el análisis de la expresión de ARNm, WB para el análisis de la expresión de proteínas, kit comercial basado en DCFDA para evaluar ROS (fluorometría), análisis de viabilidad celular por MTT y ELISA para insulina.

Resultados: el CpdA (10 $\mu \mathrm{M})$ estimuló la actividad transcripcional de Nrf2 induciendo la expresión del ARNm de enzimas antioxidantes (NQO1, HMOX-1 y Txnrd1) en células INS-1E ( $p<0,05$ vs control). Consecuentemente, el CpdA redujo la generación de ROS inducida por CYT ( $p<0,01$ vs. control). La acción del CpdA contrarrestó el aumento del índice apoptótico, cuantificado mediante la relación de la expresión de Bax/Bcl-2 y de la expresión del ARNm de DP5 (death protein-5), ambos parámetros inducidos por CYT ( $p<0,05$ vs control). EI CpdA protegió a las células INS-1E de la reducción de la viabilidad inducida por CYT y mantuvo la secreción basal de insulina ( $p<0,05$ vs control).

Conclusiones: el tratamiento con CpdA activa la vía de Nrf2 disminuyendo el estrés oxidativo y la apoptosis celular, y manteniendo la secreción basal normal de insulina cuando las células- $ß$ son expuestas in vitro a un entorno inflamatorio inducido por CYT. Actualmente, diversos experimentos continúan en curso en nuestro laboratorio para dilucidar el potencial terapéutico del CpdA en la diabetes autoinmune. 


\section{Activation of Nrf2 pathway by Compound A (CpdA) protects b-cells against cytokine-mediated inflammatory injury}

Luz Andreone $^{1}$, Carolina Sétula ${ }^{1}$, Juan Manuel Assad ${ }^{1}$, Marcelo Javier Perone ${ }^{1}$

${ }_{1}^{1}$ INSTITUTE FOR RESEARCH IN TRANSLATIONAL MEDICINE (IIMT), NATIONAL COUNCIL OF SCIENTIFIC AND TECHNICAL RESEARCH (CONICET), AUSTRAL UNIVERSITY, AUTONOMOUS CITY OF BUENOS AIRES, ARGENTINA

Contacto: luzandreone@gmail.com

Introduction: The development of the autoimmune process during type 1 diabetes (DM1) contributes to insulitis; in this context, both $\beta$-cell stress and subsequent insulin secretory deficiency precede clinical signs of disease. Hyperglycemia triggers excess production of mitochondrial reactive oxygen species (ROS) that overwhelm the anti-oxidative capacity of $\beta$-cells, leading to oxidative stress. Islet inflammatory microenvironment during the autoimmune attack contributes to the activation of oxidative and endoplasmic reticulum (ER) stress resulting in $\beta$-cell dysfunction and death. The transcription factor Nrf2 regulates the expression of cytoprotective genes in response to oxidative stress, its induction is crucial for the normal $\beta$-cell physiology. We reported that Compound $A$ (CpdA), a dissociative glucocorticoid receptor-ligand, is an effective modulator of key immune cells involved in insulitis, $T$ and dendritic cells. In addition, we observed that CpdA ameliorates cytokine (IL-1b+IFN-g; CYT)-induced ER stress in $\beta$-cells and that in vivo CpdA administration leads to a significant delay of disease onset in an accelerated murine model of DM1. The development of new agents, with anti-inflammatory and immunomodulatory action and protective potential directed against dysfunctional signaling of $\beta$-cells is of clinical interest in diabetes.

Objectives: The aim of this study was to explore the effect of CpdA on Nrf2 signaling pathway and CYT-induced oxidative stress in $\beta$-cells.

Materials \& Methods: A rat insulinoma cell line (INS-1E) was used as experimental model. CpdA chemical formula: 2-(4-acetoxyphenyl)-2-chloro-N-methylethylammonium chloride. A reporter plasmid (ARE-LUC) was used for the evaluation of Nrf2 transcriptional activity (luminometry); RTqPCR (Sybr Green) for analysis of mRNA expression; WB for protein expression analysis; a DCFDA based commercial kit to evaluate ROS (fluorometry); MTT assay for cell viability analysis and ELISA for insulin.

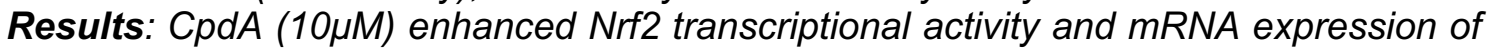
several target antioxidant enzymes (NQO1, HMOX-1 and Txnrd1) in INS-1E ( $p<0.05$ vs. control). Consequently, CpdA reduced CYT-induced ROS generation in INS-1E cells $(p<0.01$ vs. control). CpdA action counteracted the increase in the apoptotic index, quantified by Bax / Bcl-2 expression ratio, and in DP5 (death protein-5) mRNA expression, both parameters induced by CYT ( $p<0.05$ vs. control). CpdA protected against the reduction of viability and enhanced basal insulin secretion in CYT-challenged INS-1E cells ( $p<0.05$ vs. control).

Conclusions: CpdA treatment activates Nrf2 pathway decreasing oxidative stress and apoptosis and maintaining normal basal insulin secretion when $\beta$-cells are exposed in vitro to a CYT-induced inflammatory environment. Currently, several experiments are ongoing in our laboratory in order to elucidate CpdA therapeutic potential on autoimmune diabetes. 